\title{
A tribute to Professor Sergio Adamo, Full Professor of Histology and Embryology at Sapienza University, Rome
}

\author{
Bianca M. Scicchitano (1), Marina Bouchè (2), Clara Nervi (3), Dario Coletti (2)
}

(1) Sezione di Istologia ed Embriologia, Dipartimento di Scienze della Vita e Sanità Pubblica, Fondazione Policlinico Universitario A. Gemelli IRCCS, Roma, Italy; (2) DAHFMO-Unità di Istologia ed Embriologia Medica, Sapienza Università di Roma, Roma, Italy; (3) Dipartimento di Scienze e Biotecnologie medico-chirurgiche , Sapienza Università di Roma, Roma, Italy

This article is distributed under the terms of the Creative Commons Attribution Noncommercial License (CC BY-NC 4.0) which permits any noncommercial use, distribution, and reproduction in any medium, provided the original author(s) and source are credited.

\begin{abstract}
Sergio Adamo prematurely left us on January 7th 2022, just one year after his retirement, leaving his family, friends and colleagues deeply sad and grieving. Sergio was a full Professor of Histology and Embryology at the Sapienza University of Rome. Since the foundation of the Institute of Histology and Embryology more than 50 years ago, he dedicated himself to the institution, research, and teaching with integrity, generosity, and a great sense of teamwork. Sergio's main research interests have been the mechanisms of myogenesis, muscle homeostasis and regeneration under normal and pathological conditions. Most relevant results obtained by Sergio and his collaborators indicate novel functions for the neurohypophyseal hormones, vasopressin and oxytocin, upon striated muscle differentiation, trophism, and homeostasis. Here we like to give the proper tribute to a mentor, a colleague and a sincere friend. He left an indelible mark on the professional and personal lives of all of us and his absence provokes a profound sense of emptiness.

"The trouble with the world is that the stupid are cocksure and the intelligent are full of doubt." Bertrand Russell
\end{abstract}

Key Words: Skeletal muscle; Neurohypohyseal hormones; cachexia.

Sergio Adamo, full Professor in Histology and Embryology at the Sapienza University of Rome, passed away on January 7th, 2022 leaving his family, friends, and colleagues with a profound sense of sadness. He had retired just one year earlier, but he was still an active participant within the Department and the academic community. He was a well-known and highly respected scientist and teacher. Since the foundation of the Institute of Histology and Embryology more than 50 years ago, he dedicated himself to the institution, research, and teaching, always with integrity, generosity, and a great sense of teamwork. He joined the Institute when he was still a Medical student, when Valerio Monesi, the father of the Histology discipline in Rome, moved there to establish an innovative and active research center. Sergio started his research activity within the myogenesis group, coordinated by Mario Molinaro, who was developing a line of research aimed to study cell differentiation, among the few, at that time, establishing primary cell cultures as experimental strategy. ${ }^{1,2}$ After a period at the NIH in Bethesda, where Sergio improved his expertise in cellular biochemistry,

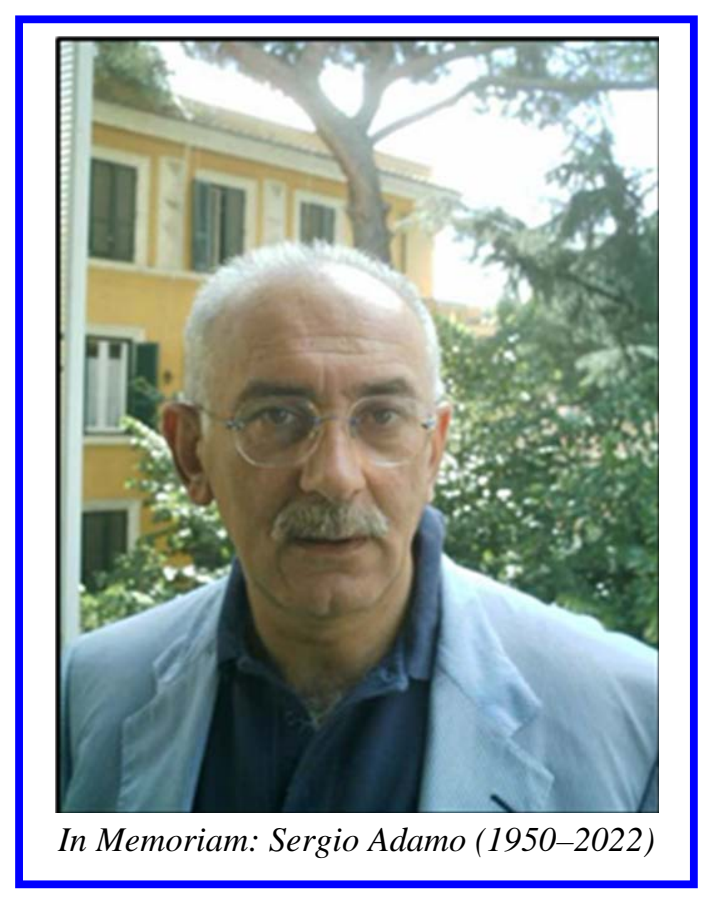


he returned to Rome in 1978, and established his own laboratory, making his contribution towards the understanding of the regulation of in vitro myoblasts differentiation. ${ }^{3,4}$ Since then, he continued his research in muscle biology, using both in vitro and in vivo experimental models.

As a full Professor of Histology and Embryology since 1990, and for many years as a coordinator of the Ph.D. program in Morphogenesis and Engineering Tissue, he was a scientific guide and an inspiration for all the students and colleagues as a person of the highest integrity, honesty, and sincerity. Likewise, as a Director of the Histology Department from 2007 to 2010, he worked tirelessly in improving the academic standing not only for his lab but also for the entire community. Sergio's main research interests were focused on muscle homeostasis and regeneration under normal and pathologic conditions. ${ }^{1-16}$ The most relevant results obtained by Sergio and his collaborators indicate novel functions for the neurohypophyseal hormones, vasopressin (AVP) and oxytocin (OT), which regulate skeletal muscle differentiation, trophism, and homeostasis. In particular, Sergio's group demonstrated for the first time that AVP promotes muscle differentiation, hypertrophy, and regeneration through the combined activation of the calcineurin and Calcium/Calmodulin-dependent Protein Kinase (CaMK) pathways. $^{5-9}$ Sergio's studies revealed that the AVP system is impaired in several neuromuscular diseases, suggesting that AVP may act as a physiological factor in skeletal muscle. This prompted Sergio to investigate the role of AVP in vivo demonstrating in a murine model that local over-expression of the AVP receptor $\mathrm{V} 1 \mathrm{a}$ enhances the regeneration of atrophic muscle. Indeed, by upregulating the regeneration/differentiation markers, modulating the inflammatory response, and attenuating fibrogenesis, the stimulation of AVPdependent pathways creates a favorable environment for efficient and sustained muscle regeneration and repair even in the presence of elevated levels of the inflammatory cytokine $\mathrm{TNF}^{10-15}$ All these studies performed by Sergio's group highlight a novel in vivo role for AVP-dependent pathways, which may represent an interesting strategy to counteract muscle decline in aging or in muscular pathologies. ${ }^{13}$ All of the above prompted to verify whether neurohypophysial hormones might be proposed as a hormonal treatment to counteract cancer-induced muscle wasting, as well. Indeed, circulating concentration of OT was found reduced in cancer patients, and its administration in a pre-clinical model of cancer cachexia appeared to be promising: these results are currently submitted for publication and represent a cue strongly suggesting that the use of neurohypophysial hormones has potential clinical applications. Additional contributions to counteract cachexia come from his group's studies on the mechanisms underlying the impairment of muscle stem cells in cachexia and countermeasures, such as physical exercise. ${ }^{16}$

The area of interest of Sergio's group recently spread also in the mechanisms underlying muscle denervation and the pathophysiology of Duchenne Muscular Dystrophy (DMD), focusing in both cases on the role of HDAC4 in muscle fiber atrophy and on mechanisms of sarcolemma repair. ${ }^{16}$

We all had the opportunity to work with Sergio, either enjoining his laboratory or closely collaborating in research and teaching. He has been an extraordinary support for all of us, and we all established a profound friendship together with a working relationship. His passion for science was truly contagious and he was a generous, open-minded, and helpful mentor and collaborator, always willing to listen and truly pleased to see the progress of our achievements and success. We also had a lot of fun with him, pleased by his sharp humor, always searching for new jokes to share. Do you remember his mustache bended by the ironic but always friendly smile? This is the way we evoke our Sergio, professor at Sapienza, scientist, and friend: gentlemanly but funny, exciting but calm, pleasant but strict, upstanding. A honest person. His teaching will remain in all of us, students and colleagues, spread around the world, forever. Many people will miss him, we will certainly miss him sorely.

Bianca, Marina, Clara, Dario

When I joined Monesi's group in 1969 as assistant professor, Sergio Adamo together with Marco Conti, two young students at the Medical School, were already there, the first to be present in Monesi's lab. Indeed, when Valerio Monesi was appointed as professor of Histology in 1968, his lab was an empty small space inside the Institute of Anatomy, and Sergio and Marco represented the founder germ of the new histological institution, helping Monesi in moving furniture, mounting shelves, and planning about the future. I was immediately attracted by Sergio's curiosity, his desire of knowledge and experimental ability. Sergio was promptly involved in setting up a model of myogenesis in primary cultures, laying the foundation the future studies on satellite muscle cell differentiation and their role in muscle growth and repair. Since then, we never stopped our long-lasting collaboration. Many qualities were harmoniously fused in Sergio's person. His sudden death left a sense of sadness for the loss of a friend, a colleague, a teacher, a just man.

Mario Molinaro

\section{List of acronyms}

AVP - Arginine Vasopressin

CaMK - Calcium/Calmodulin-dependent Protein Kinase

DMD - Duchenne Muscular Dystrophy

OT - Oxytocin

TNF - Tumor Necrosis Factor 


\section{Contributions of Authors}

All contributors approved the manuscript and agreed with publication.

\section{Acknowledgments}

N/A

\section{Funding}

None

\section{Conflict of Interest}

The authors declare no conflict of interest.

\section{Ethical Publication Statement}

We confirm that we have read the Journal's position on issues involved in ethical publication and affirm that this report is consistent with those guidelines.

\section{Corresponding Author}

Bianca Maria Scicchitano, Sezione di Istologia ed Embriologia, Dipartimento di Scienze della Vita e Sanità Pubblica, Fondazione Policlinico Universitario A. Gemelli IRCCS, Roma, Italy.

ORCID iD: 0000-0002-9599-6642

Bianca Maria Scicchitano: biancamaria.scicchitano@unicatt.it

\section{E-mails and ORCID iD of co-authors}

Marina Bouchè: Marina.Bouche@uniroma1.it

ORCID iD: 0000-0002-0938-5360

Clara Nervi: Clara.Nervi@uniroma1.it

ORCID iD: 0000-0001-9341-0188

Dario Coletti: Dario.Coletti@uniroma1.it

ORCID iD: 0000-0001-7373-1953

\section{References}

1. Adamo S, Curci A, Molinaro M, Siracusa G, Monesi V. Cell fusion and creatine kinase activity in cultures of chick embryo myoblasts. Bolletino di Zool. 1975; 42: 49-56.

2 Adamo S, Zani B, Siracusa G, Molinaro M. Expression of differentiative traits in the absence of cell fusion during myogenesis in culture. Cell Differ. 1976 Apr;5(1):53-67. doi: 10.1016/00456039(76)90015-4.

3 Bouché M, Adamo S, Molinaro M. Specific TPAinduced protein phosphorylations in cultured myotubes. Cell Biol Int Rep. 1983 Mar;7(3):189. doi: 10.1016/0309-1651(83)90219-9.

4 Bouche, M; Angelini, A; Zani, BM; Adamo, S; Molinaro M. Studies on the mechanism of action of a tumor promoter in cultured cells. J Exp Clin Cancer Res. 1985; 4: 97-106.

5 Adamo S, Caporale C, Nervi C, Ceci R, Molinaro M. Activity and regulation of calcium-, phospholipid-dependent protein kinase in differentiating chick myogenic cells. J Cell Biol. 1989 Jan;108(1):153-8. doi: $10.1083 / j c b$. 108.1.153.
6 Nervi C, Benedetti L, Minasi A, Molinaro M, Adamo S. Arginine-vasopressin induces differentiation of skeletal myogenic cells and upregulation of myogenin and Myf-5. Cell Growth Differ. 1995 Jan;6(1):81-9.

7 Scicchitano BM, Spath L, Musarò A, Molinaro M, Adamo S, Nervi C. AVP induces myogenesis through the transcriptional activation of the myocyte enhancer factor 2. Mol Endocrinol. 2002 Jun;16(6):1407-16. doi: 10.1210/mend.16.6.0854.

8 Scicchitano BM, Spath L, Musarò A, Molinaro M, Rosenthal N, Nervi C, Adamo S. Vasopressindependent myogenic cell differentiation is mediated by both $\mathrm{Ca} 2+/$ calmodulin-dependent kinase and calcineurin pathways. Mol Biol Cell. 2005 Aug;16(8):3632-41.

9 De Arcangelis V, Coletti D, Canato M, Molinaro M, Adamo S, Reggiani C, Naro F. Hypertrophy and transcriptional regulation induced in myogenic cell line L6-C5 by an increase of extracellular calcium. J Cell Physiol. 2005 Mar;202(3):787-95. doi: 10.1002/jcp.20174.

10 Moresi V, Pristerà A, Scicchitano BM, Molinaro M, Teodori L, Sassoon D, Adamo S, Coletti D. Tumor necrosis factor-alpha inhibition of skeletal muscle regeneration is mediated by a caspasedependent stem cell response. Stem Cells. 2008 Apr;26(4):997-1008. doi: 10.1634/stemcells.20070493. Epub 2008 Feb 7.

11 Toschi A, Severi A, Coletti D, Catizone A, Musarò A, Molinaro M, Nervi C, Adamo S, Scicchitano BM. Skeletal muscle regeneration in mice is stimulated by local overexpression of V1avasopressin receptor. Mol Endocrinol. 2011 Sep;25(9):1661-73. doi: 10.1210/me.2011-1049. Epub 2011 Aug 4.

12 Renzini $\mathrm{A}$, Benedetti $\mathrm{A}$, Bouchè $\mathrm{M}$, Silvestroni L, Adamo S, Moresi V. Culture conditions influence satellite cell activation and survival of single myofibers. Eur J Transl Myol. 2018 May 29;28(2):7567. doi: 10.4081/ejtm.2018.7567.

13 Pigna E, Sanna K, Coletti D, Li Z, Parlakian A, Adamo S, Moresi V. Increasing autophagy does not affect neurogenic muscle atrophy. Eur J Transl Myol. 2018 Aug 23;28(3):7687. doi: 10.4081/ejtm.2018.7687.

14 Sorrentino S, Barbiera A, Proietti G, Sica G, Adamo S, Scicchitano BM. Inhibition of Phosphoinositide 3-Kinase/Protein Kinase B Signaling Hampers the Vasopressin-dependent Stimulation of Myogenic Differentiation. Int J Mol Sci. 2019 Aug 27;20(17):4188. doi: 10.3390/ijms20174188.

15 Adamo S, Pigna E, Lugarà R, Moresi V, Coletti D, Bouché M. Skeletal Muscle: A Significant Novel Neurohypophyseal Hormone-Secreting Organ. Front Physiol. 2019 Jan 8;9:1885. doi: 10.3389/fphys.2018.01885. 
In Memoriam: Sergio Adamo (1950-2022)

Eur J Transl Myol 32 (1): 10434, 2022 doi: 10.4081/ejtm.2022.10434

16 Renzini A, Marroncelli N, Cavioli G, Di Francescantonio S, Forcina L, Lambridis A, Di Giorgio E, Valente S, Mai A, Brancolini C, Giampietri C, Magenta A, De Santa F, Adamo S, Coletti D, Moresi V. Cytoplasmic HDAC4 regulates the membrane repair mechanism in Duchenne muscular dystrophy. J Cachexia
Sarcopenia Muscle. 2022 Feb 15. doi: 10.1002/jcsm.12891. Epub ahead of prin..

Submission: February 28, 2022 Accepted for publication: March 1, 2022 